\title{
"This affair is about something bigger than John Bright": Iowans Confront the Jim Crow South, 1946-1951
}

\section{S ZEBULON BAKER}

ON OCTOBER 23, 1951, the members of the Drake University Athletic Council somberly convened in the office of their chairman, Professor Frank Gardner. Nearly 72 hours had passed since their football team arrived home after a defeat at Oklahoma A\&M, only to be thrust into the national spotlight-not for the play of their All-America halfback, Johnny Bright, but for the injuries he sustained. On three successive plays in Drake's first drive, A\&M lineman Wilbanks Smith leveled him with high, hard blows to the face long after the ball had moved down field. By the time Drake tallied its first touchdown, Bright's jaw was broken, sidelining him for the rest of the day and, as it happened, the entire season. Once Bright was out, Smith ceased his reckless tactics. If not for Des Moines Register photographers Don Ultang and John Robinson, who vividly captured the attack in photographs that indicated premeditation, the incident would likely have been waved off as another illustration that football is a violent sport.

I am grateful to the State Historical Society of Iowa for a 2011-12 SHSI Research Grant, which supported my work on this article. This article also draws on primary source research conducted under the auspices of the Elmer L. Andersen Research Program Scholars Grant (Archives and Special Collections, University of Minnesota-Twin Cities) and Special Collections Travel Grant (Special Collections, Washington University in St. Louis).

THE ANNALS OF IOWA 72 (Spring 2013). (C) The State Historical Society of Iowa, 2013. 


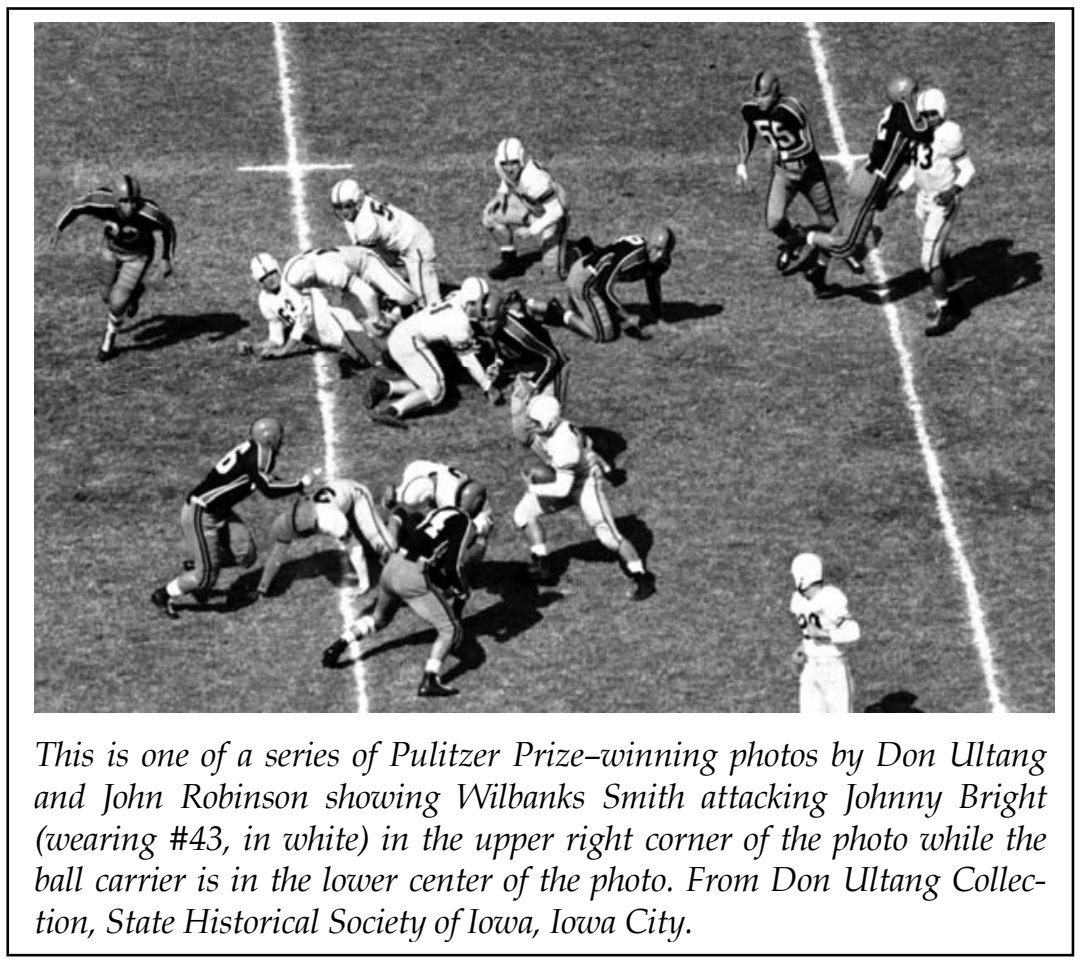

The irreducible fact that Bright was an African American rendered Smith's hits far more than rough play. With the photographs plucked off wire services by newspapers in every corner of the country, those faculty members who composed Drake's Athletic Council were faced with a full-blown crisis that grew by the hour as Smith and his head coach, J. B. Whitworth, issued repeated denials that Bright was targeted. As the councilmen gathered to watch the assault unfold on the game films, they knew that they had to counter such lies by giving voice to the truth the pictures already spoke. Because of his race, they asserted, "there was obvious intent to injure Bright with unnecessary roughness."1

1. Minutes of the Athletic Council, 10/23/1951, Folder "Bright, Johnny - Alum," Drake Biography Files, Drake Heritage Collections, Cowles Library, Drake University, Des Moines (hereafter cited as DBF); Don Ultang, interview by Brian Thomas, 6/5/1999, Iowa Digital Library, University of Iowa Libraries, Iowa City. On the Bright incident, see, generally, Jessica Lynn Schultz, "Moments of 
Before this game, it was an article of faith throughout Iowa that Bright - who had led the nation in rushing the previous two seasons as well as when he took the field on that sweltering Oklahoma Saturday - was a virtual lock for the Heisman Trophy. The professors who winced as grainy footage showed him being slammed onto that same field had placed their faith in the belief that sport offered an arena for racial progress, where the competitive rights of African Americans were guaranteed. Both dreams now seemed as shattered as Bright's jaw. If anything, Smith hammered home a warning from southern universities that they would not abandon Jim Crow in the postwar age without a fight.

The councilmen's sullen silence as the projector rattled to a noisy stop registered the message as received. When they began to speak, the emotional tenor of their conversation betrayed a deep cynicism about whether the Missouri Valley Conference - of which Drake and A\&M were members, joined by an equal split of integrated and segregated institutions - could preserve the openness of spirit that allowed Bright to participate in the first place. ${ }^{2}$ For the council, "A\&M's toleration of such conduct" indicated a retrenchment of old patterns that would hold black participation at bay, making sport yet another fortress in which Jim Crow found sanctuary. Ultang and Robinson's photos peeked past the parapets, revealing a brutal defense of the competitive color line. ${ }^{3}$

Impact: Race, Injury, and Football History in Iowa's Collective Memory" (Ph.D. diss., University of Iowa, 2005); and Lane Demas, Integrating the Gridiron: Black Civil Rights and American College Football (New Brunswick, NJ, 2010), esp. chap. 4. Drake University's Cowles Library maintains an outstanding digital archive on Johnny Bright and the Bright incident online as part of the Drake Heritage Collections; it can be accessed at www.lib.drake.edu/heritage/bright.

2. During most of the period this article examines - roughly 1946 to 1951 - the Missouri Valley Conference included, in addition to Drake and Oklahoma A\&M, Bradley University and the Universities of Detroit and Wichita, which, like Drake, featured black players on their athletic teams; and Saint Louis University, University of Tulsa, and Washington University in St. Louis, which, like A\&M, segregated their teams. By the end of 1951, another segregated institution, the University of Houston, was invited to join the league, which tilted the balance in favor of whites-only teams for the rest of the decade. In 1957 Oklahoma A\&M - by then, renamed Oklahoma State-would withdraw from the conference to join the Big Eight Conference.

3. Minutes of the Athletic Council, 10/23/1951. Drake did not officially resign from the Missouri Valley Conference for another six weeks, but the decision 
That defense introduced a new dimension into intersectional play that called for much more than what the council termed "a mere reversal of the score." Rather, when one professor suggested that Drake cut its ties with A\&M, Gardner roared that such a move was "the least Drake could do": it could leave the league. If the southern members of the conference let Smith go unpunished, he posited, the violence destined to follow "endangered" all of Drake's black athletes - and their right to play. Better to resign the conference altogether than see this right assailed by "that sort of sport." 4

It was a radical step, taken by a group of unlikely radicals. All men, all white, all conservative midwesterners, the councilmen who packed Gardner's office had just placed the honor of Drake's black students - ones with extraordinary athletic abilities, mind you - above all else, even football itself. "We acted in the only way we could," argued one participant in the meeting, "and maintained the honor and tradition of Drake." More than that, the hundreds of letters sent "from persons in all walks of life and from all parts of the country" signaled how "the move has had almost universal support." 5

Nowhere was that support more universal-or visceralthan at home in Iowa. From Denison to Des Moines to Davenport, the incident represented, in the judgment of one group from Clear Lake, "a flagrant violation not only of football rules, but of human decency." Every shutter-click of Ultang and Robinson's cameras exposed the competitive realities of southern football to Iowans caught unaware, opening their eyes, Ultang later observed, "to a social problem that hadn't been recognized in the sports world" before Bright's assault. "Suddenly," he noted, "they found out a black man could be knocked around ... deliberately." 6

to do so was made in this meeting. Concern for Drake's other black athletes was well placed; there were five others besides Bright in its football program: Alfred Brown, Leslie Eddins, Noel Harris, Norm Johnson, and William Roberson.

4. Minutes of the Athletic Council, 10/23/1951.

5. Henry G. Harmon, Report of the President to the Drake University Board of Trustees, 12/14/1951, Folder "Bright, Johnny - Alum," DBF.

6. Brad Hughes et al. to Henry G. Bennett, 10/21/1951, folder 9, box 18, OSU Presidents Papers, 1908-1968, Special Collections and University Archives, 
This epiphany pushed football fans statewide toward the same conclusion as the councilmen: southern football was a world apart, governed by a resurgent degree of racial violence that in the postwar era proved, to the minds of one Des Moines husband and wife, "a travesty on our way of life." Jim Crow never seemed so real for Iowans as he did in this moment. And his face was that of Smith, whose "gangster tactics and deliberate ruthlessness" brought home the intolerance underlying segregation for one Des Moines woman who lived near the Drake campus. Writing to Smith at his dormitory, she asked him, "Was your action stimulated by the fact that John Bright is a Negro?" But Iowans already knew the answer to that question. In the days following the game, stories circulated of white spectators laying bets in the stands on how long it would take to injure Bright. Compared to "Good Honest Football as played in Iowa," alleged one group, this event revealed how the encompassing culture of southern football - players and fans alike"didn't have the courage to face the Drake squad with Johnny Bright playing, so they resorted to hoodlum tactics to get him out." For a school superintendent in Spencer, the attack demonstrated something far more fundamental about southern values. An individual who "ignores, condones, and alibis the disgraceful act" seen in this game was, in his view, "afraid to take any constructive stand on the side of justice." 7

When it came to football, at least, Iowans believed they were on the side of justice. Since the end of World War II, racial

Oklahoma State University Libraries, Oklahoma State University, Stillwater, OK (hereafter cited as OSUPP); Ken Fuson, “Drake Great Johnny Bright Dead at 53," Des Moines Register, 12/15/1983.

7. Mr. and Mrs. L. W. Matthews to Henry G. Bennett, 10/21/1951, folder 9 , box 18, OSUPP; Mrs. A. J. Pesetski to Wilbanks Smith, 10/21/1951, ibid.; Anonymous (signed "Several Fans of Good Honest Football as played in Iowa") to Henry G. Bennett, undated [10/22/1951], ibid.; W. F. Johnson to Henry G. Bennett, 10/23/1951, folder 10, ibid. Drake fans who attended the game in Stillwater, or heard from those who had, recounted the betting that took place in the stands and the rumors swirling through the A\&M campus before kickoff about how the home team intended to harm Bright early in the first half. See, generally, J. M. Flynn to J. B. Whitworth, 10/25/1951, folder 10, box 18, OSUPP; and "Material Presented by Jack McClelland, Director of Athletics, before the Missouri Valley Conference Investigating Committee," undated typescript [November 1951], folder “Bright, Johnny - Alum," DBF. 
reconciliation through gridiron competition was a facet of the college game that Iowa's pigskin enthusiasts considered an inviolable proposition. So was the guaranteed right to play. "As long as they are members of an Iowa team," insisted the Cedar Rapids Gazette in March 1950, black athletes should "have the right to play with it wherever it appears and that right should never be signed away" in a game contract "with an opponent which refuses to compete against Negroes." 8

This unswerving determination that every athlete should be free to compete, regardless of race, was the animating principle of a wider activism that swept the landscape of college football in the state of Iowa in the five years between the first postwar season of 1946 and Bright's assault in 1951. Iowans of all stripes advocated the elimination of the competitive color line, and, for a time, it looked as if they might do it. Progress expanded on the demands of average fans that their state's brand of football stand for more than mere wins and losses. "It is my sincere belief," a booster in Spencer told Paul Brechler, athletics director at the University of Iowa, "that colleges and universities, above all other places, should be free of bigotry." Such idealism reckoned with harsher truths that afternoon at Oklahoma A\&M. "It is not easy," Frank Gardner keened, "to watch dreams die as a result of foul play." 9

An avatar of these dreams, Bright embodied for Iowans the promise of racial progress before his attack as surely as he did the loss of it thereafter. His injury brought down the curtain on a half-decade of reform, a bitter end to the widespread notion that Jim Crow could be licked by sport alone, while presaging a darker resistance to the sort of racial equality that Iowans championed. From that point forward, argued a Guthrie Center man, Iowans would harbor "a marked distaste" for all teams southern,

8. "Where Foresight Counts," Cedar Rapids Gazette, 3/5/1950, clipping in folder "No. 93, 1949-1950," box 250, Virgil M. Hancher Papers, University of Iowa Archives, University of Iowa, Iowa City (hereafter cited as UIA).

9. Paul Cooksey to Paul W. Brechler, 11/22/1950, folder “No. 84-89, 19501951," box 270, Hancher Papers; Frank N. Gardner, "Preliminary Statement to the Missouri Valley Conference Investigating Committee," undated typescript [November 1951], folder "Bright, Johnny-Alum," DBF (hereafter cited as Gardner Statement). 
which they reflexively regarded as defenders of Jim Crow and the values that precipitated this violence. ${ }^{10}$

Their anger and action in the aftermath of the Bright incident, however, cannot be fully comprehended without first coming to terms with their optimism and organization for lasting racial change in the years before this game. The striking synchronicity of campus activism, public opinion, and institutional policy during this period already concluded segregation to be a moral, cultural, and competitive evil sharply at odds with the democratic values they believed their racially diverse teams represented in every contest. Where administrators presumed that the black athlete's ability to compete in every game qualified as a defense of democratic values, other Iowans would hold that such values should be advocated on and off the field. "We differ only in our approach to the same problem," noted Virgil M. Hancher, president of the University of Iowa. In this way, the galvanic response to the Bright incident brought together the elements of this activism, bonding them so as to render the equality of each competitor - as athlete and man-a touchstone of justice on the gridiron in Iowa. ${ }^{11}$

This article explores how those "guarantees of justice," in Gardner's phrase, evolved in the world of Iowa football. Iowans embraced racial equality on the gridiron in this postwar period as the embodiment of democratic values, and they saw sports, generally, as a vehicle for combating the broader problems of racism in American life. However, the Bright incident demonstrated the white South's continued determination to resist such efforts, thereby raising questions about the extent to which sports could engender cultural transformation. Plotting Bright's assault along a longer arc of Iowa's own racial history shows how interracial play articulated homegrown competitive sensibilities that would distinguish Iowa's college teams for the intentionality of black participation. Interracial play was an act made revolutionary by Iowans' insistence on these guarantees, signaling how this overwhelmingly white state came to see, as the Drake Times-Delphic observed in 1947, that "race . . . has no

10. R. Y. Taylor to Henry G. Bennett, 10/22/1951, folder 9, box 18, OSUPP.

11. Virgil M. Hancher to Doris M. Morgan, 12/26/1950, folder “No. 84-89, 19501951," Hancher Papers. 
bearing on capabilities." The refusal of their southern opposition to adopt a similar definition on the gridiron convinced Drake, Iowa, and Iowa State to retreat from competition compromised by racism. If that transformation could not be effected in the South, then these institutions would initiate it at home, putting their nondiscrimination principles into practice. It was a legacy, Gardner concluded, that demonstrated how "this affair is about something bigger than John Bright." 12

ON THE SAME DAY that Drake's Athletic Council met to consider its response to Bright's attack, James H. Foster, an undergraduate at the University of Iowa, sat down behind a desk in the Pi Kappa Alpha fraternity house and, in longhand, "contemptfully" [sic] composed a letter to Oklahoma A\&M president Henry G. Bennett. Foster had grown up in Des Moines, mere blocks from the Drake campus; friends from his Roosevelt High days were now Bright's classmates. Bright's assault proved more than a news event for him: it was personal. He was not alone. "As it is," he told Bennett, "Oklahoma A\&M has gained 225,000 enemies in Des Moines, 2,750,000 in Iowa, and countless others across the country." For every last one of them, "there is no doubt but that the incident was planned," a searing lesson in Jim Crow values. "I realize that you and your fellow Southerners hold Negroes in contempt," he observed. "While we don't associate with them socially in Iowa, we show respect and admiration where they are due." The "amazing" outpouring of support among "students here at the University of Iowa [who] have rallied behind Drake" showed Bright to be a man worthy of just such esteem. All that Bennett's team earned was "disgrace." For Foster, "the great spirit and exceptional sportsmanship of Southern and Southwestern football teams" was forever shown to be a fraud. After this event, he informed Bennett, "I now feel only hate for your brand of football." 13

12. Gardner Statement; "We Can Help Erase Racial Discrimination," Drake Times-Delphic, 11/21/1947.

13. James H. Foster to Henry G. Bennett, 10/23/1951, folder 9, box 18, OSUPP . Foster was not inflating the outrage on his campus over the Bright incident. On the same day as his letter was written, the Daily Iowan ran an editorial, directly beneath Ultang and Robinson's photographs, that declared how "the 
The stark truths that came into focus in Ultang and Robinson's photographs offered an even starker contrast for Iowans between the values of their home state and those of the South. "I can't understand why your coach wanted to win your game enough," Foster wrote Bennett, "that he would stoop to arrange the permanent injury of an All-American . . . by such foul means." A writer for the Alton Democrat, on the other hand, thought such violence easily understood. "Bright was a colored boy and was playing football against a southern team" that knew that it "had to break [his] jaw" to win. Football in the South was, by his account anyway, "positively vicious." One former Missouri Valley Conference football player from Cherokee was well acquainted with the tactics that southern teams deployed at will: "the dirtiest, yellowest, meanest thing a white man can do-and this is especially true in the South on the home field before partisan fans - is to strike or deliberately foul a Negro on an opposing team." A Des Moines salesman was not so sure that it was the players alone who derived pleasure from watching a black man beaten in public. He urged Bennett to take a second look at the photographs. "If, after looking at the pictures of the game,

incident . . concerns SUI in several ways," not least of which was that "it happened in our backyard." Because "Drake is an Iowa team," there was "a personal meaning to the Bright incident"; "we cannot be indifferent to a neighbor's house on fire." The editorial called on the university's student government to lodge a formal protest, but Student Council president John L. Bunce begged off in a letter to the Daily Iowan the next day. "For the University of Iowa to enter into this matter by way of a protest from the student body," he maintained, "would be banal under these circumstances for the issue is not one in which we as a student body are engaged actively." An incredulous sophomore responded, in his own letter to the Daily Iowan, "It is not only our responsibility, but our duty as students of SUI, to take an active interest in last Saturday's football happenings in Oklahoma," if only because "every man is his brother's keeper." The letters and telegrams collected in OSUPP include several written by students at the University of Iowa, but the student government did not formally protest the incident on behalf of its own constituents or in solidarity with Drake. See "The Bright Incident," Daily Iowan, 10/23/1951; John L. Bunce to Editor, Daily Iowan, 10/24/1951; and John O. Seesser to Editor, Daily Iowan, 10/26/1951. See also "Says Bright Not Purposely Hurt," Daily Iowan, 10/23/ 1951; Alfred M. Anderson to Editor, Daily Iowan, 10/24/1951; William I. Hetherington et al. to J. B. Whitworth, Daily Iowan, 10/24/1951; David R. Bowers to Editor, Daily Iowan, 10/24/1951; Stewart C. Crockett to Editor, Daily Iowan, 10/26/1951; Phil Bigelow to Editor, Daily Iowan, 10/26/1951; and Dorothy T. Walker and Sam H. Walker to Editor, Daily Iowan, 10/26/1951. 
you still insist on defending [Smith]," he argued, "you must be judged lacking in a sense of fair play just as Mr. Smith will be judged by all sports loving people throughout the country." Studying the images for herself, one native Oklahoman living in Des Moines told Iowans to take heart. "As far as racial prejudice is concerned," she crowed, Iowans "are at least 50 years ahead of Oklahomans." 14

That was a shifting mark. Iowa was not the South - that much was true. But acceptance of free and unfettered black participation in Iowa football was a decidedly postwar concept. Throughout the interwar seasons of the twenties and thirties, Iowa's universities simply accepted racial violence as one of the unfortunate but unavoidable aspects of competition for black football players. "There's no use kidding anyone," remarked Ossie Solem, Iowa's head coach in 1934, "a Negro player, even if his opponents play cleanly, always gets plenty of bumps and particularly when he is a star ball carrier." His comments addressed the beatings his highly touted running back, Oze Simmons, endured that season, especially at home against the University of Minnesota, whose whites-only team knocked Simmons cold twice. Minnesota president Lotus D. Coffman dismissed the widespread "inference" afterward "that the players on the Minnesota team were in someway or other antagonistic to Mr. Simmons because he is a Negro." Such an inference, he scoffed, was "silly and ought not to be given credence by thoughtful men." 15

The recent past, however, showed other black players from Iowa having a rough go of it against the Golden Gophers. In a letter to himself on stationary from Minneapolis's Curtis Hotel the night "before the first real college game of my life" - on October 6, 1923-Iowa State's sophomore tackle, Jack Trice, held that no less than "the honor of my race, family, and self are at stake" in his performance against Minnesota. "Everyone is ex-

14. Foster to Bennett, 10/23/1951; Chester R. Lindhoff to Henry G. Bennett, 10/23/1951, folder 9, box 18, OSUPP; "It Seems to Us," Alton Democrat, 10/25/ 1951; Bob Reeser to Editor, Des Moines Register, 10/25/1951; Audrey Loehr to Editor, Des Moines Register, 10/25/1951.

15. "Truth Out about Oze Simmons of Grid Fame," New York Amsterdam News, 11/17/1934; L. D. Coffman to H. D. Knox Jr., 11/5/1934, folder "Negro, 19211936," box 22, Office of the President Records, University Archives, University of Minnesota-Twin Cities, Minneapolis (hereafter cited as UMN). 
pecting me to do big things," he noted. "I will!" It was a pledge fulfilled with his life: a broken collarbone suffered in the first quarter augured sustained injuries in the second half, hastening his death two days later. One of his teammates, Harry Schmidt, denied rumors that Gopher players targeted him because of his race. "Absolutely not," he told an interviewer in 1973. Yet the mere suggestion was enough to worry Big Ten commissioner John L. Griffith, who had been Drake's head football coach from 1908 to 1915. "Inasmuch as Mr. Trice was a colored man," he wrote four days after Trice's death, "it is easy for people to assume that his opponents must have deliberately attempted to injure him." Griffith's own experience with "colored boys" imparted "very little to indicate that their white opponents had any disposition to foul them." After all, he declared, "one of the great glories of athletics [was] that every man, no matter who he is, is assured fair play in an athletic contest." 16

A lofty principle, no doubt, but hardly one to which universities in Iowa subscribed. Not only were black athletes like Trice and Simmons subjected to rough play from their opponents, but they also had to endure repeated blows to their dignity by their own universities concerning their right to play. They competed in an era dominated by so-called "Gentleman's Agreements" informal accords negotiated between northern and southern universities that sidelined athletes of color, all in the name of Jim Crow. To keep southern teams on their schedules, Iowa's universities abided the color line, making an athlete's race the qualifying factor for participation.

Indeed, had Trice lived another week, Iowa State leaders "had no intention of using" him in their game at the University of Missouri. On the day that he died, Mizzou athletics director C. L. Brewer contacted S. W. Beyer, Iowa State's faculty athletic chair, about him. Unaware of the events in Minneapolis, Brewer

16. Jack Trice's Last Letter, 10/5/1923, folder 8, box 1, Jack Trice Papers, Special Collections and University Archives, Iowa State University Library, Ames (hereafter cited as ISU); Harry Schmidt, interview by Bill Walsh, 12/4/1973, folder 4, ibid.; John L. Griffith to S. W. Beyer, 10/12/1923, folder 7, ibid. On Jack Trice's life and death, see Dorothy Schwieder, "The Life and Legacy of Jack Trice," Annals of Iowa 69 (2010), 379-417. On the experience of black athletes in midwestern sports generally, see Charles H. Martin, "The Color Line in Midwestern College Sports," Indiana Magazine of History 98 (2002), 85-112. 


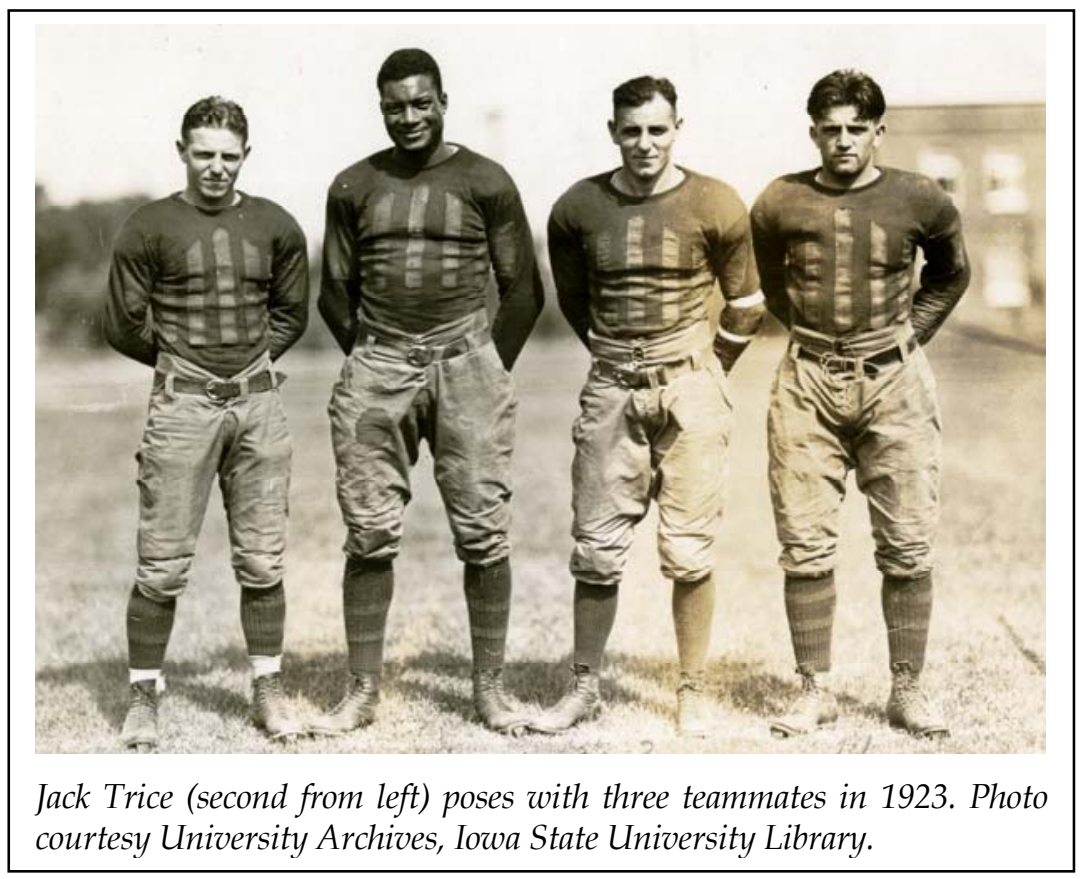

reminded Beyer of "conditions here" in Columbia. "It is impossible," he explained, "for a colored man to play or even appear on the field with any team" from Mizzou. Mindful of southern "tradition," he insisted, "we cannot permit a colored man on any team we play." The color line was drawn. For his part, Beyer replied that Iowa State, as a fellow member of the Big Six Conference, "understood for several years ... that colored men could not be used on teams playing with schools from the states of Missouri, Kansas, and Oklahoma," where Jim Crow ruled. Iowa State thus planned to leave Trice in Ames. "However," Beyer noted, "that is all settled because Jack's injury resulted in his death." 17

17. S. W. Beyer to C. L. Brewer, 10/10/1923, folder 7, box 1, Trice Papers; C. L. Brewer to S. W. Beyer, 10/8/1923, ibid. Harry Schmidt claimed that Washington University had similarly drawn the color line for Iowa State's game in St. Louis during the 1923 season. "Jack went with us," he recounted, "but he got off the train at Kirksville [MO]." Schmidt alleged that teams in Missouri "would not play against a Negro" - a charge that Brewer's letter here corroborates. However, Schmidt's memory failed him: Iowa State did not meet Washington University until October 27, three weeks after Trice's death. See Schmidt 
Although "no written rule" existed, "only a gentleman's agreement," Beyer nonetheless toed the color line. Succeeding generations of Iowa State leaders would do the same over the next quarter-century, abetting the divisions in the Big Six between integrated and segregated institutions. For the conference's two southern members-Mizzou and the University of Oklahoma - the end of World War II intensified the need to codify these agreements in their bylaws. A wave of recently discharged black veterans stood to flood onto campuses, and this pair had a vested interest in seeing that none of them crashed onto the gridiron. Accordingly, in May 1946, the president of Oklahoma's Athletic Council, Walter Kraft, aided by his Mizzou counterpart, Sam Shirky, browbeat the other four faculty representatives -including H. D. Bergman of Iowa State-into approving, unanimously, a provision that they buried deep inside the Big Six rule book, written in such a manner as to obscure its true intentions. "The personnel of athletic squads," it read, "shall be determined in accordance with the laws of the sovereign state" in which the game was played, with "the personnel of visiting squads . . . selected as to conform with any restrictions imposed upon a host institution by the sovereign authority." That is, black athletes were unwelcome in both Norman and Columbia. Afterward, Kraft advised his president, George Lynn Cross, who personally opposed the state's Jim Crow laws, that the "intense interest . . . in the negro question" compelled the action, to which, he boasted, "we all agreed." This rule yielded the desired outcome. Kansas, Kansas State, Nebraska, and Iowa State simply avoided black recruits since they could not participate in every game. It was hardly a blow to the jaw, but this bylaw knocked black players out of Big Six games all the same. ${ }^{18}$

interview. On the role of "Gentleman's Agreements" in college football, see Samuel Zebulon Baker, "Fields of Contest: Race, Region, and College Football in the U.S. South, 1945-1975" (Ph.D. diss., Emory University, 2009), esp. chap. 2.

18. Beyer to Brewer, 10/10/1923; Baker, "Fields of Contest," 42-44; Rules and Regulations Governing Athletics and All Participation of the Missouri Valley Intercollegiate Athletic Association, 1948, folder "Athletics (\#2)," box 38, George Lynn Cross Presidential Papers, Western History Collections, University of Oklahoma, Norman; Walter W. Kraft to George Lynn Cross, 5/20/1946, folder "Athletics," box 13, ibid. This rule was found in Article III, Section 5, of the Big Six bylaws. 
Kraft exerted such influence because the Big Six was a conference run by faculty members. Regardless of the opposition of institution heads to this bylaw - whether Cross or Iowa State president Charles E. Friley, who were both against this rule change - they were powerless to stop it. Only those faculty leaders charged with managing Big Six business could affect its policy. Here, they encoded prejudice as their official competitive stance.

The stoutest opposition to this provision was found among student leaders at the league's institutions, including those at the University of Colorado, which joined as the league's seventh member on New Year's Day, 1948. The students took direct aim at the bylaw in hopes that the newly constituted Big Seven membership might turn the tide in favor of black participation. The groundswell had actually started with Iowa State's student government, the Cardinal Guild, in November 1947. Its officers "reopened the question of discrimination," the Daily Nebraskan reported, "by passing a resolution at their last meeting favoring equal opportunity for individuals, regardless of race, color, or creed to participate in the [league's] athletic contests." Led by a full spate of veterans, who believed that the bylaw violated the democratic values for which they had fought in Europe and the Pacific, the Cardinal Guild leaders presented their resolution to Bergman, who, they hoped, would lay their concerns before the faculty junta at the Big Seven's winter meetings in Kansas City. "I told them I would do this," he reported to Friley, "but doubted that the Conference would take any further action." He was right. The matter was tabled at once. ${ }^{19}$

The Cardinal Guild resolution did, however, succeed in rallying students at other conference member institutions to action.

19. “Iowa State for Big Six Rule Change," Daily Nebraskan, 11/14/1947; H. D. Bergman to Charles E. Friley, 11/13/1947, folder 31, box 9, Charles Edwin Friley Papers, ISU; Minutes of the Meeting of the Faculty Representatives of the Missouri Valley Intercollegiate Athletic Association, 12/12/1947, folder "Big 6-Admission of Colorado Univ.," box 1, William H. Baughn Papers, Archives, UCB Libraries, University of Colorado at Boulder, Boulder (hereafter cited as UCB). Bergman was presented this Cardinal Guild resolution by its president, Don Delahunt, and a representative of the campus chapter of the American Veterans Committee - a clear sign that Iowa State's veteran community had a hand in crafting this resolution, inside the Cardinal Guild ranks and out. 
Harold Mozer, student body president at the University of Nebraska, asserted that "this year, with Iowa State behind us, we should be able to do something about the situation." In late November 1947 Mozer welcomed Cardinal Guild president Don Delahunt to Lincoln along with the student government presidents from four of the other five member institutions (Missouri's president attended; Oklahoma's did not) for a summit on this discriminatory rule. Their meeting produced a resolution similar to that of the Cardinal Guild: "any eligible student of a member institution shall be allowed to participate in all competitive athletic events at any member institution." A skeptical Daily Nebraskan editor sniped that Iowa State's students had accomplished just one thing: "the proverbial sleeping dog was aroused." 20

Although the Big Seven's faculty leaders rejected the joint student resolution at the same time as they tabled the one sent by the Cardinal Guild, the combined effect thawed the competitive landscape. By March 1948, Iowa State's athletics director, Louis Menze, was the first of his cohort to publicly entertain the notion of suiting up black players. "If we have any Negro boys come out, and they're good enough," he informed the Chicago Defender, "we'll play them." There was, however, one catch: "but not at Missouri and Oklahoma." A month later, a student body referendum put Iowa State undergraduates on record as overwhelmingly in favor of lifting all bans on black participation in the Big Seven. Of 5,483 ballots cast, 5,062 (92 percent) favored repealing the bylaw, making them the first student body in the league to collectively voice support for opening athletic opportunities to African Americans. ${ }^{21}$

Iowa State's faculty and administrators did not share their courage. When, in early March, the institution heads of Colorado, Kansas, Kansas State, Nebraska, and even Missouri held their own meeting about the bylaw, Friley deliberately ducked it. Nor did he sign the resolution those presidents and chancel-

20. "Iowa State for Big Six Rule Change"; "Big 6 Leaders to Confer on Racial Discrimination," Daily Nebraskan, 11/16/1947.

21. Resolution Adopted at the MVIAA Conference on Discrimination, 11/29/ 1947, folder 9, box 31, Friley Papers; "Sleeping Dog ...," Daily Nebraskan, 11/19/ 1947; "Students Poll Big Seven on Racial Ban," Chicago Defender, 3/20/1948;

"92 Percent of Iowa State Vote Hits Jim Crow," Chicago Defender, 4/10/1948. 
lors produced that called on "each institution [to] determine for itself what players are qualified" to play football. ${ }^{22}$

By May, Oklahoma's faculty senate recommended to President Cross that "any restrictions due to race in the participation of athletics at the University . . . be removed." Yet Bergman joined with Kraft in holding the line on segregated competition, voting later that same month in the Big Seven's spring meetings to keep that bylaw in the rule book. No one in a position of leadership at Iowa State was willing, as Colorado president Robert Stearns put it, to "permit a change in official attitude." 23

If Stearns had had his way, such a change would have been patterned on what Drake and its Missouri Valley Conference brethren had achieved by erasing the color line from league play in late 1947. The members of that league, in the words of the Drake Times-Delphic, negotiated "far-reaching changes in rules governing athletic competition," deciding that black athletes could compete on all conference teams and in all conference venues, starting in September 1950, regardless of local laws. Stearns approved of this approach: segregated and integrated universities arriving at "such a modification in its rules" through mutual accord. To "disturb the present alignment" in the Big Seven required a similar understanding. With the likes of Saint Louis and Oklahoma A\&M permitting black athletes from, say, Drake to play on their home fields, he figured, "it might be much easier for us to convince the University of Missouri and the University of Oklahoma of the desirability of change." 24

Not every Missouri Valley member was convinced of this desirability, though. It was a deeply conflicted league, a mis-

22. Robert L. Stearns to Milton S. Eisenhower et al., 3/8/1948, folder 2, box 72, Central Administration Records: President's Office, UCB.

23. E. E. Hatfield to George Lynn Cross, 5/17/1948, Folder “Negroes," box 34, Cross Presidential Papers; Robert L. Stearns to Reuben S. Gustavson, 1/12/1948, folder 2, box 72, Central Administration Records: President's Office, UCB.

24. "Valley League Picks Barrett," Drake Times-Delphic, 12/17/1947; Stearns to Gustavson, 1/12/1948. Colorado's faculty athletic representative, Walter B. Franklin, was not as enthusiastic about the applicability of the Missouri Valley's rule change to the situation in the Big Seven, advising Stearns that it "does not give us anything to be used as leverage upon Oklahoma University." Walter B. Franklin to Robert L. Stearns, 2/18/1948, folder 2, box 72, Central Administration Records: President's Office, UCB. 
match of members who pursued radically divergent competitive ambitions - to say nothing of their varying cultural norms. Earle Davis, faculty athletics chair at the University of Wichita, was unsure whether the league could even "survive as a working and effective organization." "We are far apart in many matters of principle," he advised conference leaders in early 1947. "Some of us do not participate in various sports; some of us do not play other schools; some of us have wildly differing attitudes toward the conduct of sports." Their concord on black participation, then, was an illusory kind of progress, suggesting that they were effecting real change, when, in fact, it was a last-ditch bid to save the conference from a seemingly inevitable dissolution. ${ }^{25}$

For their part, Drake officials would eventually blame this state of affairs on the "expansion of the conference to include schools from the Great Lakes to the Gulf of Mexico." Straddling the Mason-Dixon Line in that way "has created numerous conference problems," not least of which was whether black participation was a guaranteed right. After World War II, Drake and the other integrated members functioned competitively at odds with themselves: their black athletes could play segregated teams at home, but facing the Missouri Valley's "Southern Bloc" on the road was impossible. "Southern inhospitality" was how the Drake Times-Delphic euphemistically characterized it. To wit, Perry Harris, Drake's "fleet Negro back," who returned to campus after 38 months in the Army Tank Corps in time for the 1945 season, was left at home when his team departed for Oklahoma and a showdown with the University of Tulsa. But when the series was renewed in Des Moines the following season, Harris's coaches ruled him "available for the Tulsa tussle." For Iowans, this situation was a perversion of morality, good sense, and fair play. For white Oklahomans, though, it was a natural condition of culture. "Colored boys," stated one coach there, "are not allowed to play south of the Mason-Dixon line." 26

25. Earle Davis to Arthur H. Compton, 1/15/1947, folder "Athletics (2 of 3)," box 1, series 02 , Office of the Chancellor: Arthur H. Compton Records, University Archives, Washington University in St. Louis, St. Louis.

26. Press Release on Drake's Resignation from the Missouri Valley Conference, undated [ca. 11/27/1951], folder "Bright, Johnny-Alum," DBF; Minutes of the Athletic Council, 11/27/1951; "Bulldogs Collide with Golden Hurricane in 
All of which helps explain why Johnny Bright's appearance at Oklahoma A\&M on October 15, 1949, was so groundbreaking. Never before had an African American played a team from Oklahoma inside its own state borders. Bright's participation, as a sophomore, was a trial run for the new Missouri Valley rule. It was also a sop to the Big Seven, which A\&M officials were desperate to join, as a show of racial tolerance for a conference that finally broke the color line that season when Kansas State used Harold Robinson on Thanksgiving Day against Mizzou in a game played in Columbia. It was "not practicable or feasible," asserted Bergman, for the Big Seven to admit another segregated member. Accordingly, Bright's spot in Drake's starting line-up demonstrated to skeptical Big Seven members that, although A\&M was a segregated team, Jim Crow did not determine its visitors' rosters. On that afternoon, at least, black participation in the state of Oklahoma became a guaranteed right. ${ }^{27}$

Gardner would later recall the trepidation with which Drake officials approached the contest, worrying "how would this boy be treated" as "the first of his race to ever play on the Aggie field." Bright was not quite the sensation he was when he returned to Stillwater in 1951, but, Gardner noted, "he was already attracting attention as the nation's leading back" - which made him a ready target, no matter his race. The game was no contest, with a superior A\&M team whipping Drake, 28-0. A reporter for the Drake Times-Delphic jibed that Bright and his teammates "were so well scouted that one got the idea that the

Loop Tilt at Tulsa Saturday," Drake Times-Delphic, 10/4/1945; "Hurricane Powerhouse Rated Heavy Favorite," Drake Times-Delphic, 10/4/1946; "Misunderstanding Over Negroes Denied," Daily Oklahoman, 10/10/1946.

27. Minutes of the Meeting of the Faculty Representatives of the Missouri Valley Intercollegiate Athletic Association, 5/19-21/1949, folder 14, box 8, Director of Athletics Administrative Papers, University Archives, University of MissouriColumbia, Columbia; “Tiger Muzzles Wildcat, 34-27, Atkins Is Star," Daily Oklahoman, 11/25/1949; Bob King, "Manhattan Youth First Negro To Play in Big 7," Kansas Industrialist, 9/22/1949, file "Football, History of - Robinson, Harold," KSU History Vertical Files, Special Collections and University Archives, Hale Library, Kansas State University, Manhattan; D. Scott Fritchen, “'I Was There To Play Ball,'” Powercat Illustrated, 10/29/1999, 8-11. Unsurprisingly, the only votes among the Big Seven's faculty leaders that Oklahoma A\&M's application for conference membership could muster were cast by Walter Kraft of Oklahoma and Sam Shirky of Missouri. The five representatives from the integrated universities voted it down. 
scouts had been working out with Drake since last August." On the whole, Gardner confessed, "we were soundly trounced," with Bright tallying his fewest rushing yards of the season, "but he was happy and we were made joyful by the fact that while the game was rough and tough, this boy was played clean." Indeed, Bright told his coaches that the A\&M squad was "one of the cleanest he had played." Afterward, Gardner drafted a letter to A\&M leaders "to express our deep appreciation for the fine way in which this young back had been treated [by] the coach and members of the team." Their "exemplary conduct" toward Bright proved to Drake officials that black athletes could compete in the South without threatening their guaranteed right to play - and without violence. "Two years later," Gardner observed, ruefully, "the story was much different." 28

AT THE DAWN of the 1950s, that story remained one of increasing black participation in Iowa football-a refutation of Jim Crow values at home and in the South. "It is easier," argued the Cedar Rapids Gazette in late February 1950, "to break down the fences of prejudice in sports than in other fields." Bright accomplished that feat in Stillwater; Iowa State students demanded it in the Big Seven; now it was the University of Iowa's turn. ${ }^{29}$

On a sultry Friday night in November, nearly 45,000 spectators filed into Miami's Orange Bowl Stadium to watch the undefeated Miami Hurricanes play host to a hapless Hawkeye team. The game would end much as this hometown crowd expected - in another Hurricane victory-but, early on, Iowa showed more fight than anyone had anticipated. Racing to a 7-0 lead on its first drive, Miami's defense then faltered as Iowa quarterback Glenn Drahn hit a fluky 39-yard pass to Fred Ruck, hauled in

28. Gardner Statement; “Aggies Lasso Bulldogs, 28-0," Drake Times-Delphic, 10/19/1948; "Sports! By George," Drake Times-Delphic, 10/19/1948. Although the original did not survive, a copy of Gardner's letter to A\&M faculty athletics chair C. H. McElroy is included in A\&M's official response to the Missouri Valley Conference's investigation of the Bright incident. Its language aligns with much of what Gardner says in the quoted statement, which was made in conjunction with the same investigation. See C. H. McElroy to Investigating Committee, 11/10/1951, folder 5, box 19, OSUPP.

29. "Practicing Brotherhood," Cedar Rapids Gazette, 2/25/1950, clipping in folder “No. 93, 1949-1950," box 250, Hancher Papers. 


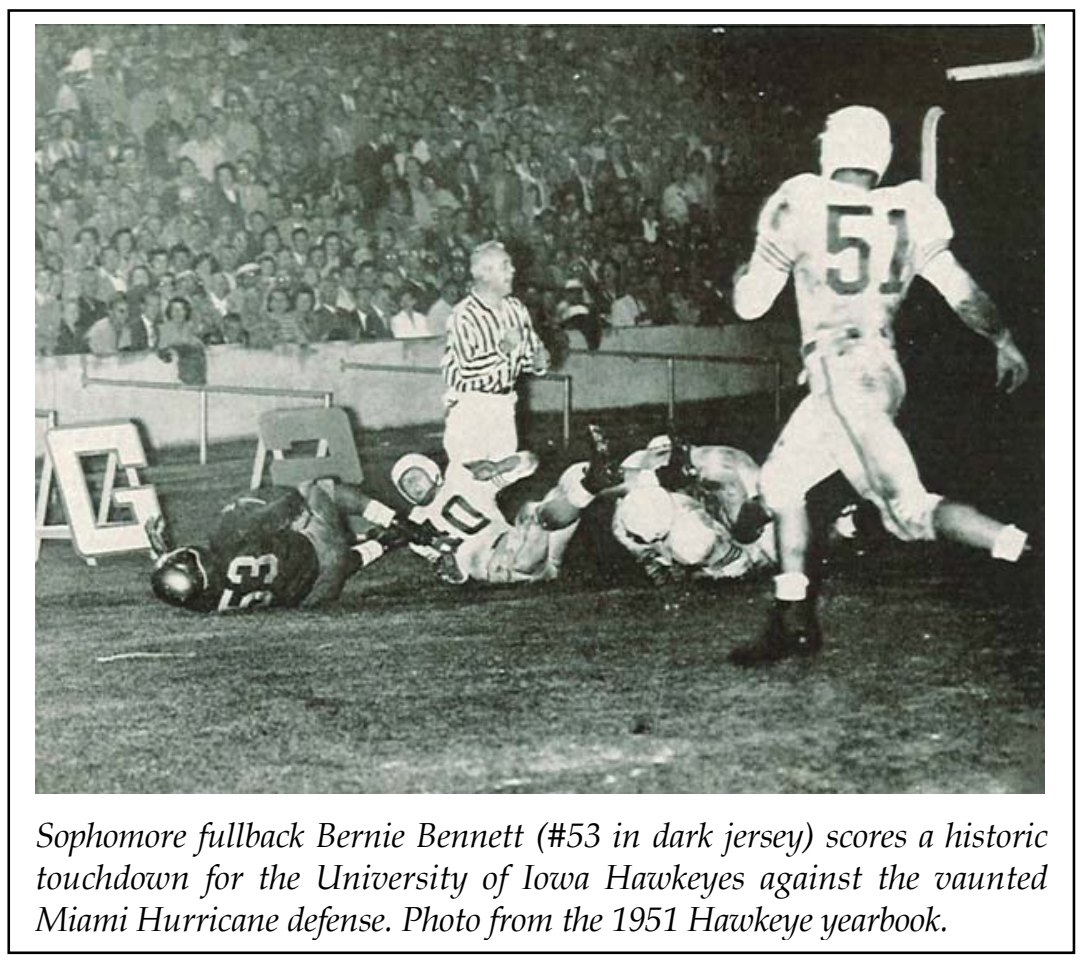

six yards shy of the Hurricanes' goal line. On the next play, Drahn swept to his right, pitching off to sophomore fullback Bernie Bennett, one of five black players to suit up for Iowa, who skirted Hurricane right end Tom Jelley to slip in the front corner of the end zone for Iowa's only touchdown. Bennett's sprint marked another first - a black athlete scoring on Miamiexactly what the 4,000 black spectators packed into the east stands paid to see. His touchdown, noted the Miami Herald, "inspired the Negro fans . . . to a wild cheer" - an unrestrainedly joyous expression of their racial pride. In his arms, Bennett cradled all their ideals, hopes and aspirations as surely as the ball itself. His achievement was theirs. ${ }^{30}$

30. “Morale May Be Factor in Miami Game Friday," Daily Iowan, 11/22/1950; "Undefeated Miami Topples Iowa, 14-6," New York Times, 11/25/1950; Jimmy Burns, "Iowa Best Team We Played This Year, Says Gus," Miami Herald, 11/25/ 1950. Besides Bennett, the Hawkeye roster included four other African Americans: Harold Bradley, Donald Commack, Donald Corbin, and Donald Riley. On the experience of black athletes at the University of Iowa generally, see David R. 
As with Bright's experience in Stillwater the previous season, Bennett and his black teammates were surprised by the lack of violence. Judging it "a nice clean game," Hawkeye head coach Leonard Raffensperger expressed appreciation for "how our colored boys were treated." Given that most of the Hurricane players were northerners, the reception the black athletes received was, to his mind, "no different than we expected." After all, his team had just faced the least southern line-up it could meet this far below the Mason-Dixon Line. "We didn't think those Miami boys from New York, Pennsylvania, or New Jersey," he remarked, with a wink, "would mind playing against our boys." This alone felt like progress - "a realization of the democratic ideal," declared one black writer. ${ }^{31}$

Yet the guaranteed right to play was not the guarantee of democratic ideals. Jim Crow made sure of that. From the start, every aspect of the contest reflected the vicissitudes of the segregated South. In March, as he was finalizing the game contract, Iowa athletics director Paul Brechler explained to his president, Virgil M. Hancher, that their team's black players were "a touchy problem" in Miami. Just weeks earlier, the University of Minnesota had conceded to local laws and left a black boxer at home for its bout there-a fact that made Brechler's efforts to avoid "any embarrassment" an imperative. However he managed it, he arrived at "an understanding" with Miami athletics director Paul Harding about black participation: "if Iowa has Negroes on its squad" - as he knew it would - "there will be no question raised as their being permitted to represent our athletic department." With pride, Brechler told Hancher, "this will be the first time that Negroes have been granted permission to play against Miami" on its own field. To mark the occasion, Harding opened the east stands to black spectators, a one-time affair that not only cashed in on their interest, but at the same time effectively increased segregation inside the Orange Bowl. One out of every ten tickets purchased went to a black patron, meaning a full

McMahon, "Remembering the Black and Gold: African-Americans, Sport Memory, and the University of Iowa," Culture, Sport, and Society 4 (2001), 63-98.

31. Lee Evans, "Iowa Coach Lauds Hawks' Fine Play," Miami Herald, 11/25/ 1950; J. S. Saundle, "Along the Horizon as One Educator Sees It," Journal of Negro Education 20 (1951), 591-95, esp. 593. 
tenth of the crowd was seated in a section that existed for one purpose alone: to separate the races. ${ }^{32}$

Back home, it was not who played or where spectators sat that concerned black Iowans, but the accommodations to which Bennett and his black teammates had been subjected. Before the Iowa team departed for Miami, Des Moines's black newspaper, the Iowa Bystander, published an editorial blasting the university for a plan to house the team's black players in private homes while its white players would stay in a swank downtown hotel. For the Bystander's publisher, James B. Morris, it amounted to "a disgraceful arrangement, an insult to the Negro players." To his thinking, the university had bowed to Jim Crow valuesand unnecessarily so. "Segregation is undemocratic and unfair," he attested, "and places a stigma upon those who are objects of the unholy practice." While social progress was achieved on the field, the black athletes were branded by segregation all the same with separate lodging. The university was at fault for failing to acknowledge how "it would be necessary to take a stand in this very matter" when it scheduled a game in a segregated city. Instead, he alleged, the university did nothing but open "the Hawkeye state to the justifiable criticism that it has entered into a mutual agreement to segregate and embarrass a portion of those who have been sent out as representatives of the institution." In a personal letter, Morris appealed to Hancher to avoid any future games "requiring an arrangement of this kind." "Out of decency, respect for the players, and in keeping with our boast of democracy," he insisted, no Hawkeye team should travel south again "unless arrangements can be made which will not subject the players to this type of thing." 33

32. Statement by President J. L. Morrill, 2/22/1950, folder "Discrimination, 1949-52," box 95, Office of the President Records, UMN; Paul W. Brechler to Virgil M. Hancher, 3/14/1950, folder “No. 93, 1949-1950," box 250, Hancher Papers. When the University of Iowa's Board in Control of Athletics gave Brechler "authority to negotiate in completing the football schedule for 1950 . . with such teams as Miami University," no mention was made in the official record of the racial complexities of scheduling the game in segregated Miami. Minutes of the Board in Control of Athletics, 2/10/1949, folder "Minutes, 1949-1952," box 3, Records of the Board in Control of Athletics, UIA.

33. "Iowa Must Not Violate Its Pledge," Iowa Bystander, undated clipping [ca. mid-November 1951], folder "No. 84-89, 1950-1951," box 270, Hancher Papers; James B. Morris to Virgil M. Hancher, 11/14/1951, ibid. 
Hancher and Brechler were flabbergasted. It simply never occurred to them that their team was participating in anything but what Hancher labeled "an event of great social significance." For them, the game was the thing-and, in this vein, they regarded their conduct before and during the trip to Miami as a defense, even an expansion, of the black athlete's right to play. "We think we have played a large part," Brechler told Morris, "in helping do away with segregation." Iowa stood up to Jim Crow on the field and, even if its team lost the game, they still defeated him. 34

Yet the victory extended only as far as the chalky in-lines of the gridiron itself. Beyond them, the black athletes were treated to the humiliating varieties of southern segregation. No matter how feverishly Brechler promised that the black players were "exceedingly well treated, and happy to have made the trip and played in the game," the guaranteed right to play assumed dimensions that no Iowa university ever envisioned: overcoming segregation on the field was a hollow victory if black athletes were resegregated away from it. Ignoring the individual rights and dignity of black athletes, Morris argued in his Bystander column, "takes an unfair advantage of these players." For black Iowans like him, this game marked no progress at all if the treatment of black players did not adhere to precepts of a democratic society. The university's commitment to the guaranteed right to play for its black athletes, protested the Des Moines Interracial Commission, could not be compromised simply "to play an intersectional football game." "Equality of accommodations," they contended, "is a privilege to which each citizen is entitled if the principles of democracy are to be upheld." 35

Like other universities throughout the state and the Midwest, Iowa was only then beginning to accord its black students the equality of accommodations that these activists demanded for black athletes. Those African Americans who applied to the University of Iowa in the thirties and forties discovered that their letters of acceptance were quickly followed by notices

34. Hancher to Morgan, 12/26/1950; Brechler to Morris, 1/17/1950, folder “No. 84-89, 1950-1951," box 270, Hancher Papers.

35. "Iowa Must Not Violate Its Pledge"; Doris M. Morgan to Virgil M. Hancher, 12/9/1950, folder “No. 84-89, 1950-1951," box 270, Hancher Papers. 
from Housing Services, insisting that "the University of Iowa does not permit Negroes to live in any of our dormitories." "Our Negroes," they were informed, relied on Iowa City's small black community for assistance. "They try to take care of their own," one incoming freshman from Minneapolis was told in February 1935. On their own, black men either rented beds in rooming houses or, as the Hawkeyes' gridiron star Oze Simmons did, lived in one of the two black fraternity houses downtown on South Dubuque Street. Black women typically found lodging in the private residences of local black families or a privately owned dormitory operated by the Iowa Federation of Colored Women's Clubs. The university would relent in this practice of segregation in 1946, when Housing Services assigned five black women to rooms in Currier Hall. For black men-especially athletes - the policy change did not come until later that decade. Meanwhile, segregated housing remained a crisis on other campuses around the state. In 1947 a pair of white undergraduates objected to a similar ban on black housing at Drake, pointedly asking in the Times-Delphic, "Is Drake a Jim Crow school?" But it was another two years before African Americans, like Johnny Bright, then a sophomore, could finally reside on campus. ${ }^{36}$

Intersectional series only amplified the inherent contradictions between principle and practice at Iowa's major universities. None of these institutions perceived the dilemma in demanding equality for black athletes on the field but treating them like second-class citizens away from it. "Men in high places," Morris wrote of the Hawkeyes' trip, "should not agree to deny a citizen all the rights and privileges to which he is entitled under the law of the land." But Iowa universities continued the practice anyway when their football teams took to the road. In 1951, when Bright and his teammates arrived in Stillwater for that fateful game with Oklahoma A\&M, the hotel at which they

36. W. H. Cobb to W. T. Middlebrook et al., 9/29/1941, folder "Negroes, 193942," box 22, Office of the President Records, UMN; F. E. Holmes to Arnold B. Walker, 2/9/1935, folder "Negro, 1934-41," box 10, Office of the Dean of Students Records, UMN; Richard M. Breaux, "'Maintaining a Home for Girls': The Iowa Federation of Colored Women's Clubs at the University of Iowa, 1919-1950," Journal of African American History 87 (2002), 236-55; William Green and Joe Massik to the Editor, Drake Times-Delphic, 11/26/1947; "Progress Report," Drake Times-Delphic, 2/25/1955. 
had stayed in 1949 now denied Bright a room. Without any lodging, Bright and Drake officials scrambled to find an alternative for him, which ended up being the private home of a local black minister - just the sort of segregated accommodations to which Morris had objected. Two years later, Iowa State's first black players, Harold Potts and Hank Philmon, bunked in a black-owned funeral home the night before their junior varsity team took on Mizzou in Columbia. The precedent had been set, and ingrained, which caused Morris to lament that black players "should be a party to a deal of this kind." 37

Yet off-field discrimination was irrelevant for most Iowa football fans. "It appears," one booster apprised Brechler, "that the department is making every effort to combat prejudice and segregation where it is met" - especially if that meeting was on the gridiron. From the vantage of history, it is clear that, by the start of the 1950s, when Iowa's universities entered into a series against a southern opponent, "stipulated from the beginning," Hancher maintained, "was the condition that any Negro players ... would play in the game." Institution-to-institution relationships in this matter required full agreement, he noted, or else the prospect of competition was "refused." What happened off the field - as in lodging-did not bear upon whether the contest was scheduled. In this case, since hoteliers, not the University of Miami, had discriminated against the athletes, the University of Iowa, in Hancher's telling, "did not cancel its contract with a University that did not discriminate because of the discrimination practiced by the hotel owners." Socially segregating its black athletes from its white ones in a city governed by Jim Crow was merely the price to be paid, in his judgment, for helping interracial play "become commonplace." After all, this game, he averred, "moved another step toward the solutions we seek" namely, no forced disruptions in the services of its best players. ${ }^{38}$

37. "Iowa Must Not Violate Its Pledge"; Jeff Olson, "50 Years Later: Reliving the Johnny Bright Story," Des Moines Register, 10/13/2001; Ultang interview; Morris to Hancher, 11/14/1951.

38. Cooksey to Brechler, 11/22/1950; Hancher to Morgan, 12/26/1950. There is evidence that the Iowa-Miami game did change the culture of southern football, at least with regard to the University of Miami. By 1957, Miami president Jay F. W. Pearson could attest that his fans had become accustomed to watching integrated teams play the Hurricanes in the Orange Bowl. "Our public," he 
"LICKING THE PROBLEM of discrimination could be accomplished only by Negroes continuing to go into the South." So answered a faculty member when Drake's athletics director, Jack McClelland, asked the Athletic Council, in a meeting just ten days after Bright's assault, "if we should subject" athletes of color to "the discrimination they invariably received in the South," competitively and culturally. For McClelland, "the question of continuing to play our men against schools in the South was one for serious consideration," particularly when weighed against "the possibility of another "incident.'" "Sending teams to compete in the South" was, to his way of thinking, a chancy proposition, offering a definitive challenge to the university's policy of "treating colored athletes the same as white ones." 39

McClelland's concerns touched the heart of the problem: Was intersectional competition fair to black athletes? Despite the attack that their best player had just endured, these councilmen believed that traveling south was worth the risk, asserting - against overwhelming photographic evidence - that "the race problem in sports is considerably better than it was some years ago." McClelland tempered his doubts by mouthing similar platitudes. "Perhaps the best thing about this entire incident," he sighed, "was the help it might give in the lessening of racial discrimination the country over." Progress was happening in Iowa, no doubt. The question was whether the South would follow suit. From where McClelland was sitting, the violence in Oklahoma made those odds long, indeed. He reminded the councilmen of "the sort of men Drake has to deal with in the Missouri Valley Conference-men who do not think as we do." What's more, he warned, "Drake has alienated most of the Conference schools." Its offense? Seeking justice for an African American. ${ }^{40}$

told a presidential colleague, "does like to see teams from other major conferences and other independents like Notre Dame and Pittsburgh." The Hurricanes would not integrate their own football program until the mid-sixties, but in the meantime their fans did not object to racial diversity in their opponents' rosters. See Jay F. W. Pearson to J. Wayne Reitz, 2/13/1957, folder "Correspondence, SEC, 1955-57," box 54, J. Wayne Reitz Presidential Papers, Department of Special and Area Collections, University of Florida, Gainesville.

39. Minutes of the Athletic Council, 10/30/1951.

40. Ibid. 
For the sort of men Drake had to deal with in its conference -the so-called Southern Bloc-no cause was more offending. They made it abundantly clear after Bright's assault that they would shield Oklahoma A\&M, in general, and Wilbanks Smith, in particular, from ever facing justice. Jim Crow would be defended. For the Drake Athletic Council, the bloc "seemed to be pursuing a deliberate policy of procrastination" as a way to frustrate Drake's determined drive to see Smith penalized. The bloc would stall hearings, cast aspersions on Drake's motives, even accuse McClelland of selling doctored photographs to Des Moines newspapers. Worse yet, the chairman of the league's investigating committee-a professor at Tulsa-informed Frank Gardner that, although "A\&M had a pitifully weak case," no punishment for Smith was imminent, ensuring that he would get away with assaulting Bright. So much for justice. ${ }^{41}$

The Missouri Valley's ultimate refusal to punish Smith not only incensed football fans across Iowa, but caused them to appreciate, for the first time, how black participation in an age of Jim Crow was not about competition alone; it was also a matter of justice. The guaranteed right to play, the rights of black athletes away from the field, the intersection of interracial play with principles of democracy - these aspects of the growth in diversity in Iowa football were implicated in the search for justice. The Missouri Valley membership, in the eyes of most Iowans, chose to forgive Smith but condemn Bright for being an outstanding athlete-and African American. "Such reprehensible and unsportsmanlike conduct and discrimination against a player because of color or outstanding ability as with Johnny Bright," argued a Waterloo man, "cannot be shrugged off." Yet that was precisely what the Southern Bloc would do, leaving Drake with what Gardner judged the "not very desirable alternative" of making good on its pledge to resign from the conference. 42

In one final appeal for Smith to be held to account, Drake president Henry Harmon attended a gathering of Missouri Val-

41. Minutes of the Athletic Council, 11/16/1951, 10/30/1951. Oklahoma A\&M athletics director Henry Iba claimed that McClelland was guilty of "showing pictures to the press."

42. D. B. Smith to Henry G. Bennett, 10/22/1951, folder 9, box 18, OSUPP; Minutes of the Athletic Council, 10/30/1951. 
ley presidents in mid-November, where it was apparent that bloc members would withhold justice for Bright. When Harmon asked his presidential colleagues "if the Conference refused to condemn the incident," they all answered that they planned to make no statements one way or another. Baffled, he then inquired "if they denied the legitimacy of Drake's protest." Again, they would stay silent. To a man, they confessed that Smith was guilty. "But," Harmon reported to the Athletic Council, "they were still unwilling to act." Privately, he confided in McClelland that Drake could never expect to receive any measure of justice from them. Far from leading league leaders to a moment of moral clarity, Bright's attack offered "a fine opportunity for the Southern schools to reintroduce the ban on Negro athletes or for the Conference to create a situation that would force out some of the Northern schools." Showing Drake the door would allow them to "swing the Conference to the South and the Southwest" and reestablish "a Conference that practices segregation" - an association sure to deny justice to athletes of color. 43

By that 1951 season, such a conspiracy no longer seemed farfetched. The sports pages were filled with stories of midwestern institutions dealing with the racism of their southern counterparts. The week of Bright's assault featured two such items involving Drake's Missouri Valley brethren. Three days before Bright and his teammates traveled to Stillwater, wire reports carried news of the cancellation of a November 24 game between Bradley and Florida State, to have been played in Tallahassee. Despite the on-field progress made when black athletes from the University of Iowa played in Miami, Florida State officials declined Bradley's request that its black players be guar-

43. Minutes of the Athletic Council, 11/27/1951; Memorandum, Henry G. Harmon to Jack McClelland, 11/15/1951, folder "Bright, Johnny - Alum," DBF. There was some credence to Harmon's allegations about the desire of the Southern Bloc to transform the Missouri Valley into a segregated, southern conference. In May of that year, the Southern Bloc had attempted to expand the league membership to include another of their ilk, Texas Tech. "In case of a dissenting vote on the part of the northern schools" about Texas Tech's application, the Daily Oklahoman reported, "a bloc of southern schools in the Valley might pull away and form a loop of their own with Texas Tech as a member." No doubt, Harmon would have been aware of Texas Tech's application and the divisions it laid bare in the conference. See "Valley Gathers, Deny League Split Rumor," Daily Oklahoman, 5/11/1951. 
anteed a right to play, hastily pulling the plug on this date as well as on their return engagement in Peoria, Illinois, in 1952. Bradley athletics director A. J. Bergstrom was unapologetic. "If these four men can't participate," he insisted, "neither can the rest of the Bradley team" - a natural position, given the Missouri Valley's own rules. ${ }^{44}$

Yet the Daily Oklahoman considered southern teams willing to use "deliberate mayhem" to win. A renewed campaign to marginalize and brutalize black athletes was essential to their project of unscrupulous success, witnessed that Saturday in Stillwater-and in Tulsa. There, rough treatment of Marquette University's black players by Tulsa's entire team prompted both institutions to terminate contracts for their future meetings. The Daily Oklahoman believed that the world of southern football, "tainted with thuggery," was drifting further from the national mainstream, with Ultang and Robinson's photographs illustrating the distance. "Some of our Southwestern institutions," one Des Moines salesman mourned, "must 'win at all costs.' " 45

Rough play was one thing. But the spirit of the play in Stillwater - a concerted effort not just to limit Bright's effect, but to take him out-went well beyond hard-nosed competition, a fact impressed upon the Drake team throughout their trip. One player, George Smith, visited a local barber shop, where the patrons "bet a certain amount of money that John Bright would not finish the game." Another of Bright's teammates, Jim Peterson, was told by a scared A\&M student that head coach J. B. Whitworth had prodded his players in practice all week "to take care of John Bright, whatever it takes, even if you have to kill him." Multiple players and coaches heard rumors that Whitworth's assistants made the slogan for that week's practice simple: "Get Bright." Other stories told of these assistants screaming at players in defensive drills to "get that nigger" or "get that coon." 46

Whatever was said or done in practice, Gardner believed it "extremely important to find the source of this intent." He urged

44. "Bradley Game Cancelled," New York Times, 10/18/1951; “This Is 1951, Boys!" Baltimore Afro-American, 10/27/1951.

45. "This Hurts All Oklahoma," Daily Oklahoman, 10/26/1951; Lindhoff to Bennett, 10/23/1951.

46. Warren Gaer Statement, 10/23/1951, folder “Bright, Johnny - Alum,” DBF. 
the Missouri Valley's investigating committee to focus its inquiry on what factors influenced Smith to act as he had. "If he is a mild person," as A\&M officials said he was, "the provocation to intent must have been all the more intense and strong." Whitworth and his staff either "directly or indirectly instilled in him pregame ideas," but "were their slogans and 'battle cries' of such a nature that a 'mild young man' goes suddenly berserk on the very first scrimmage play of the game?" Smith's intent had a source, but the southern members hardly wanted to find it. ${ }^{47}$

To pinpoint what prompted Smith to attack Bright would have meant traversing the gulf that was opening, not just between Drake and its southern opponents, but between the values of equality and access, which Iowa football fans believed to be hallmarks of this postwar age, and a closed and provincial southern society, encumbered by its fealty to Jim Crow. The Bright incident suggested that southern values were so inherently racist that its universities and their teams could not be trusted to know the right thing, let alone do it. It was a failure of institutions, cultural and educational. This assault, then, was, for one Drake fan, not only an "unsportsmanlike act" - it was also "un-American." That feeling suffused the outrage. "There are many here in Iowa and the Middlewest," KRNT sports director Al Coupee reported, "who are convinced that Smith attacked Bright in violation of every principle of American sportsmanship." There was no need to play an opposing team that could not be trusted to play fairly, or whose "type of play," Gardner asserted, "destroys the very canons of normal human decency." 48

Decency was never Jim Crow's calling card: violence, misery, heartbreak - that was more his style. Drake and its supporters - and, of course, Bright himself-had more than their fill of his manner, his values, his influence over an athlete who was in thrall to the cruelty of prejudice, whose actions, Harmon told Drake's board of trustees, were "below the whole intent and purpose of the game." The university, he said, should have no affiliation with a conference that "hesitated to take any action

47. Gardner Statement.

48. J. Stuart Kirk to Henry G. Bennett, 10/24/1951, folder 9, box 18, OSUPP; Al Coupee, "Letter to Aggie Head," Drake Times-Delphic, 10/26/1951; Gardner Statement. 
against the Oklahoma school because it believed that the college would ignore any action that was taken." Nor should Drake associate with institutions that deliberately refused to accept that Bright's injuries were, in Gardner's phrasing, "intentional beyond reasonable doubt." With no punishments forthcoming, with Smith continuing to play as if nothing had happened, with Bright's brilliant college career cut tragically short, Drake's Athletic Council was left with no other recourse than to fulfill its pledge. On November 27, 1951, Drake resigned its membership in the Missouri Valley Conference. In solidarity, Bradley tendered its notice as well. With the Universities of Wichita and Detroit the only remaining northern schools, the Missouri Valley was now a southern conference, by right. "Alas," Bradley's faculty athletic chair, Philip Becker Jr., wrote to Gardner, "the villain has stolen the scene." 49

WHEN WORD of Drake's resignation circulated through campus, reported the Times-Delphic, students "overwhelmingly" supported the move. Seeing few alternatives, most of them echoed the proud insistence of one upperclassman that pulling up stakes and moving on was "the only thing we could do." A brother in the Alpha Tau Omega fraternity guaranteed a repeat of the violence inflicted on Bright if Drake stayed put, given the Missouri Valley's indifference to the motivations behind his assault. "If nothing was done," he postulated, "this type of situation could just keep happening." And then there was the matter of Bright's honor. "We should withdraw," asserted one of the star player's senior classmates, "in respect to John Bright alonewho did so much and expected so little." Still, no matter how strongly they felt that this stand was made on principle, students fretted about the prospects for Drake's "Bright-less" future as an independent. "I think the action was justified," confessed one Kappa Kappa Gamma sorority member, "but I don't think we'll be having any good games any more." 50

49. Harmon, Report to Drake Board of Trustees, 12/14/1951; Gardner Statement; Philip Becker Jr. to Frank N. Gardner, 12/4/1951, folder “Bright, Johnny Alum," DBF.

50. "Students Support University Action Against Valley," Drake Times-Delphic, 11/30/1951. The Times-Delphic polled 45 students: 29 favored Drake's departure 


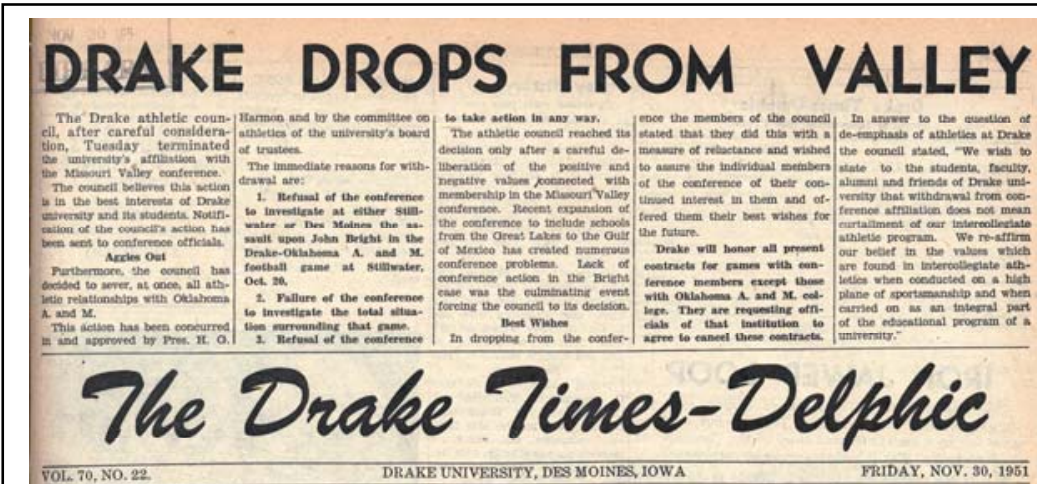

\section{SFC To Underwrite First Military Ball}

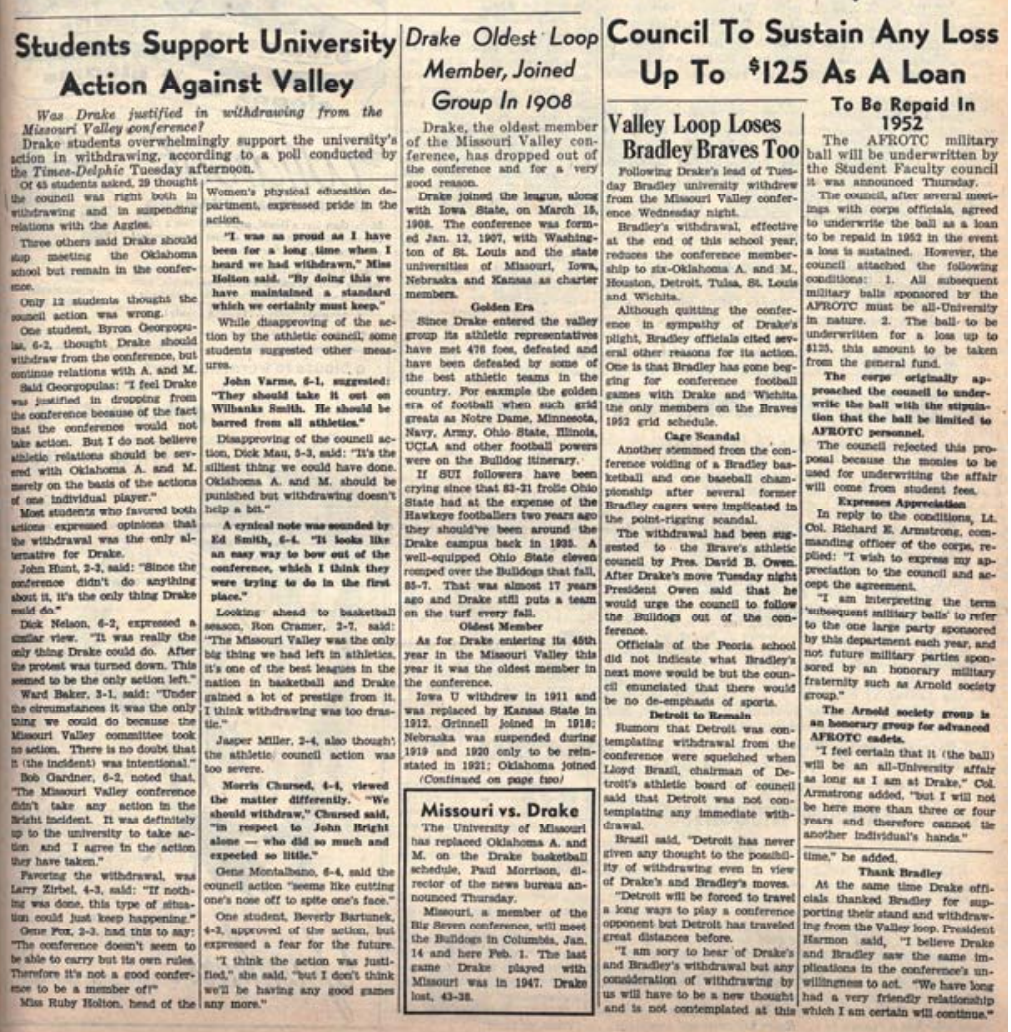

Drake University's withdrawal from the Missouri Valley Conference was the subject of four of the top five stories on the front page of the November 30, 1951, issue of the Drake Times-Delphic. Image courtesy of Cowles Library Archives, Drake University. 
She was more right than she could ever know. Trading profit for principle meant that Drake's independence from 1952 to 1956 lacked the drama of a conference championship race or the national spotlight of a star player. Fans lost interest as Drake endured one losing season after another, leaving Drake Stadium embarrassingly empty during home games. By 1954, the football program's operating deficit was upwards of $\$ 20,000$, a crushing sum for a university that depended on gameday revenue. "Very anxious to get in a conference," President Harmon pressed Gardner and McClelland to secure a new league affiliation, which, by September 1955, they found, improbably, in the Missouri Valley. A unanimous vote of the league membersincluding Oklahoma A\&M-ushered Drake back into the fold, an acknowledgment of what both sides had lost in the Bright incident. Drake needed its rivalries with Wichita, Tulsa, and Bradley (which resumed its membership in 1955 as well) to increase gate receipts. The Missouri Valley needed its traditional northern anchor. Bygones could be bygones, in Gardner's view, if it might "stimulate attendance." 51

Yet by the time that Drake made its prodigal return, the Missouri Valley was hardly the same conference. Southern members still dominated, yes, but the guaranteed right to play for black athletes was standing policy, in large part because their own football programs were now integrated. The composition of those southern teams on Drake's regular season schedules before and after the Bright incident indicates just such a transformamation (see table). Where Drake had routinely faced segregated foes in the six seasons prior to its withdrawal-in some years, playing as many as four whites-only squads on a slate of nine games - in the post-Bright era it never competed against opponents who toed the color line, even as the resumption of its Missouri Valley membership in 1957 returned the university to sustained contact with the world of southern football. Its teams

from the Missouri Valley Conference; 3 believed that Drake could simply stop playing Oklahoma A\&M, while maintaining its conference membership; only 12 opposed the university's resignation outright.

51. Harmon, Report to Drake Board of Trustees, 12/14/1951; “Drake To Keep Football-Harmon," Drake Times-Delphic, 1/12/1954; "Drake Resumes Missouri Valley Status," Drake Times-Delphic, 9/14/1955. 
TABLE

Iowa Universities Against Southern and Segregated Opposition, 1946-1966 (regular season contests only)

\begin{tabular}{|l|l|c|c|c|c|}
\hline \multicolumn{2}{|c|}{} & $\begin{array}{c}1946- \\
1951\end{array}$ & $\begin{array}{c}1952- \\
1956\end{array}$ & $\begin{array}{c}1957- \\
1961\end{array}$ & $\begin{array}{c}1962- \\
1966\end{array}$ \\
\hline $\begin{array}{l}\text { Drake } \\
\text { University }\end{array}$ & $\begin{array}{l}\text { No. of Games Against } \\
\text { Southern Teams/ } \\
\text { Segregated Teams }\end{array}$ & $14 / 14$ & $0 / 0$ & $8 / 0$ & $9 / 0$ \\
\hline $\begin{array}{l}\text { Iowa State } \\
\text { University }\end{array}$ & $\begin{array}{l}\text { No. of Games Against } \\
\text { Southern Teams/ } \\
\text { Segregated Teams }\end{array}$ & $12 / 12$ & $10 / 9$ & $12 / 0$ & $16 / 1$ \\
\hline $\begin{array}{l}\text { University } \\
\text { of Iowa }\end{array}$ & $\begin{array}{l}\text { No. of Games Against } \\
\text { Southern Teams/ } \\
\text { Segregated Teams }\end{array}$ & $1 / 1$ & $0 / 0$ & $1 / 1$ & $2 / 2$ \\
\hline
\end{tabular}

were not facing the racially hostile likes of Oklahoma A\&M, but, rather, North Texas State, which, in signing two African Americans, Abner Haynes and Leon King, to football scholarships in 1956, kept pace with the kinds of competitive change that enabled Drake to reenter conference play without violating its stand against Jim Crow. Indeed, Drake's first trip below the Mason-Dixon line since that day in Stillwater was made to Denton, Texas, on October 5, 1957, to meet Haynes, King, and their North Texas teammates. (Drake would win, 19-6.) The regularity of black participation on the Drake squad, as well as on nearly all of the other league teams, revealed to the North Texas coaches, explained historian Ronald E. Marcello, that "recruiting other blacks in future years" was critical if their own program "were to remain competitive" in the Missouri Valley. It was an epiphany that guaranteed that Drake would be facing more Abner Hayneses and fewer Wilbanks Smiths. ${ }^{52}$

52. Ronald E. Marcello, "The Integration of Intercollegiate Athletics in Texas: North Texas State College as a Test Case, 1956," Journal of Sport History 14 (1987), 286-316, esp. 309. The use of black athletes throughout the Missouri Valley Conference expanded in the late fifties and early sixties, except at the University of Tulsa. Although Tulsa allowed visiting African Americans to compete on its home field, there is evidence of fan abuse, even into the early sixties. Indeed, when Drake's basketball team played there in early 1964, Tulsa fans hurled ice and racial epithets at Drake's black players. "It is a shame," railed the editor of 
Drake's guarded reengagement with southern football mirrors generally the experiences of the University of Iowa and Iowa State, whose schedules indicated a similar reluctance after 1956 to square off against opponents who insisted upon segregation. Although Iowa State continued to face Missouri and Oklahoma's whites-only squads in Big Seven play until 1956, both institutions had long abandoned their opposition to black participation, clearing the way, by the early 1950s, for African Americans to join Cyclone football for the first time since World War II. The same was true at Iowa. The Hawkeyes, for instance, began their 1958 national championship season with Texas Christian, whose tolerance for African Americans on its opponents' rosters was recognized across the Midwest. "Laest yeah," one Texan explained to the Daily Iowan, which lampooned his accent, "weal whupped Ohiah Staet an lost ah owun confrurence titul, so this yeah weal lost to Ahiowah and weal going to win tha Saouthwes titul." Black players or not, "ouah boys wun't wurried abah this game." Perhaps they should have been more concerned about Iowa's black stars, such as Bob Jeter, who reeled off a 42-yard touchdown run, or John Burroughs, whose strong tackling helped to keep them out of the end zone all day. ${ }^{53}$

Texas Christian was the first southern university that Iowa had played since the Bright incident, which Iowa athletics director Paul Brechler had denounced at the time in a letter to Drake's Athletic Council. Because of his "indignation" at Bright's treatment, he refused to slate southern opposition. Similarly, Iowa State faculty athletics chair H. D. Bergman would contest Oklahoma A\&M's admission to the Big Seven for another five years. After Bergman persuaded Colorado and Nebraska to join with Iowa State in defeating A\&M's expansion bid in December 1954,

the Times-Delphic, "that such a great basketball conference as the Missouri Valley has to be ruined by a team that bases a game on bigotry and intolerance." "Is It All in the Game?" Drake Times-Delphic, 3/3/1964.

53. Lou Younkin, "Iowa Hawkeyes Favored Over TCU Horned Frogs Today," Daily Iowan, 9/27/1958; "Post-Game Comments," Daily Iowan, 9/30/1958. Iowa's three southern opponents in the post-Bright era-Texas Christian in 1958, North Carolina State in 1965, and the University of Miami in 1966-each fielded all-white teams when they played the Hawkeyes. However, these institutions were well known for agreeing to interracial play and did not make the participation of Iowa's black athletes an issue in scheduling their games. 
Kansas chancellor Franklin Murphy consoled A\&M president Oliver Willham with the promise that "it is only a matter of time" before their institutions would be conference colleagues. However, one Oklahoma City sportswriter counseled disappointed A\&M fans that a Big Seven invitation was inconceivable so long as Iowa State could play up "sympathy" for Bright. 54

When A\&M was finally granted membership in 1957, its athletics director and head basketball coach, Henry Iba, pledged "to bring our athletic program in stride with the Conference." That meant bringing African Americans into its segregated program, for Missouri and Oklahoma had integrated their teams by that time. It would be another three years, in September 1960, before the newly styled Oklahoma State program made its Big Eight Conference debut-a delay demanded by Iowa State to guarantee that this newest member did indeed recruit athletes of color into its football program. An integrated league would abide segregation no more. 55

SUCH PROGRESS made on the field did not ensure progress away from it. Just because the color line was being erased from the gridiron did not mean that Iowa universities were scrubbing it clean from their own campuses. "Since we know that our fine University Community of Ames is blighted by prejudice," a local minister remarked in 1963, the first step to eradicating this scourge was to stop "pretending it does not exist." After all, he asserted, "in the Midwest, we are tempted to believe that we are isolated from the problems of racial discrimination." 56

54. Minutes of the Athletic Council, 10/23/1951; Flynn to Whitworth, 10/25/ 1951; Franklin D. Murphy to Oliver S. Willham, 1/5/1955, folder "Athletic Office, 1954-55," box 1, series 2/11/5, Chancellor's Office Records, Kenneth Spencer Research Library, University of Kansas Libraries, University of Kansas, Lawrence.

55. H. P. Iba to Franklin D. Murphy, 5/20/1957, folder "Athletic Office, 195657," box 1, series 2/11/5, Chancellor's Office Records; Volney Meece, "Big Seven Officials Again Reject Cowpokes," Daily Oklahoman, 12/12/1954. Chester Pittman signed with Oklahoma State in the spring of 1958 as its first African American football player.

56. Russell L. Fate to Editors of the Daily Tribune and Iowa State Daily, 1/29/1963, folder 16, box 9, James H. Hilton Papers, ISU. 
That illusion of a color-blind society was enough to persuade at least one black student to attend Iowa State. When a young freshman from Charleston, South Carolina, named Harvey Gantt, enrolled there in the fall semester of 1960, he learned immediately that it was "really a considerably different place than I had thought it would be." There were few black students. "In fact," he recalled in 1986, "there weren't many blacks anywhere." Prevented by segregation from attending Clemson Agricultural College, Gantt, using his National Merit Scholarship and funds from a state-sponsored program to pay for African Americans to study outside South Carolina, enrolled at Iowa State to major in architecture. It was not the prospect of studying architecture, however, that had lured him to Ames. Rather, he confessed, "I was mesmerized by the big-time college football" that the Cyclones played "and seeing so many black athletes and assuming that the schools [in the Midwest] were a lot more integrated than they were." The "complicated" reality for African Americans at Iowa State was that "very few blacks matriculated... and those that did were primarily athletes." So pervasive was this reality, Gantt recalled, that most of the white students he met in his first days on campus "assumed that I was playing on the football team, which insulted me and was degrading." 57

When Gantt finally won admission to Clemson in federal court in late January 1963, he was reminded "how different that was immediately from Iowa State": the janitors at Clemson were black. Although he was the first African American to enroll in a traditionally white university in the state of South Carolina since the age of Reconstruction, Gantt was not the only person of color on campus, for Clemson was populated by a network of black service workers who told him that "we're going to take care of you." "As a matter of fact," he noted, "Clemson turned out to be blacker" than Ames, which he had expected to be more open and fair than the South because it allowed minorities to play football. The presence of black athletes on Iowa's football teams masked those deeper problems of discrimination in student life at Iowa's universities, which blinded administrators

57. Harvey B. Gantt, interview by Lynn Haessly, 1/6/1986, Interview C-0008, Southern Oral History Program Collection, Southern Historical Collection, Wilson Library, University of North Carolina at Chapel Hill, Chapel Hill. 
to the challenges still facing black students, and called into question the nature of an integrated university. ${ }^{58}$

The confluence of those dilemmas was seen in October 1961 on the Daily Iowan's editorial page. When its editors reprinted a column from the Daily Texan, the student newspaper at the University of Texas, calling for the recruitment of African American athletes to its own football team, one Iowa student reminded his fellow Hawkeyes that "unfortunately, we ... are in no position to be smug." "Yes," he conceded, "we have permitted Negro athletes to perform in sports events." In fact, "we are willing to spare no expense to encourage their participation." Nevertheless, there was still work to be done at Iowa. African Americans were not permitted to join the university's all-white Greek system. Nor did the university defend the rights of black students to live in off-campus housing without facing discrimination from local landlords. For that matter, its officials were slow to acknowledge any complaint of discrimination on campus - a tell-tale sign, for this student, that issues of racial progress possessed a relevance beyond the brick walls of Iowa Stadium. "The antebellum attitude at Texas U. has, at least, the virtue of consistency," he jibed. "Ours, on the other hand, is a curiously unprincipled code" - a code, that is, that conveyed to Iowa's black students that "you can participate FOR us - but not WITH us." 59

58. Ibid.

59. “On Athletic Integration at a Texas University," Daily Iowan, 10/4/1961; Larry Barrett to Editor, Daily Iowan, 10/7/1961. At the University of Iowa, for instance, the same administrators who insisted on equal access to the gridiron for black athletes shied away from fighting for similar measures of equality for black undergraduates. President Hancher was reluctant to intervene in civil rights disputes that arose in off-campus housing or fraternity membership. Many students saw his tentative approach as emblematic of an institutional disinclination to "seriously consider" discrimination on campus and in Iowa City. A few professors even were of the mind that "as an educational institution ... the university should not take a stand on a political problem," an anxious stance that refused to combat Jim Crow's influence in their own midst. Even when Hancher finally approved a general policy on discrimination in late April 1960, he offered but pale support for the "general aims or goals" of the new regulations. "We all strive," he allowed, "for a 'climate' of no discrimination." See Robert Fulton to Donald E. Boles, 4/6/1960, folder 6, box 2, Records of the Committee on Student Life, UIA; Corrected Minutes of Committee on Student Life, 4/4/1960, ibid.; Policy re Organizational Discrimination, April 1960, ibid.; Press Release, 4/29/1960, ibid. 
That this editorial dustup arose ten years to the month since the Bright incident indicated the endurance of these matters long "after the heat of the battle," as Harmon described it to Gardner. The gridiron supplied a frame for white Iowans in which the essential values of a democratic society-fair and open access to opportunity, rewarded ability, social progress through education - could be defended, if not expanded, by the competitive ambitions of their universities' football programs. When asked to break this frame and consider the applicability of these values to their everyday lives, white Iowans proved generally incapable of translating such advocacy to a world beyond the gridiron. By contesting Jim Crow's influence over football in the segregated South, they were given license to overlook his cruel handiwork at home. "Racial prejudice exists in Des Moines," observed Patti Miller, a Drake student who would participate in the Mississippi Freedom Summer of 1964. "People are killing and beating others with their thoughts." Except, by the mid-sixties, Iowans did not need to look for this violence-physical or psychic-in Oklahoma, but in "the white backlash" that Miller saw materializing in her hometown and on her own campus toward the approaching reckoning with Jim Crow. To defeat the values of segregation once and for all, Iowans of all stripes would have to take a stand in the interests of progress as surely as they had for pigskin. "Now," Miller concluded, "we have something to fight." 60

60. Henry G. Harmon to Frank N. Gardner, 12/5/1951, folder "Bright, Johnny - Alum," DBF; Jane Bartley, "Views Racial Situation after Mississippi Project," Drake Times-Delphic, 9/25/1964. In my conclusions here on the intersections between civil rights and life in postwar Iowa, I have been most influenced by my readings of Noah Lawrence, "'Since it is my right, I would like to have it': Edna Griffin and the Katz Drug Store Desegregation Movement," Annals of Iowa 67 (2008), 298-330; George William McDaniel, "Catholic Action in Davenport: St. Ambrose College and the League for Social Justice," Annals of Iowa 55 (1996), 239-72; and Katrina M. Sanders, "The Burlington Self-Survey in Human Relations: Interracial Efforts for Constructive Community Change, 1949-1951," Annals of Iowa 60 (2001), 244-69. 